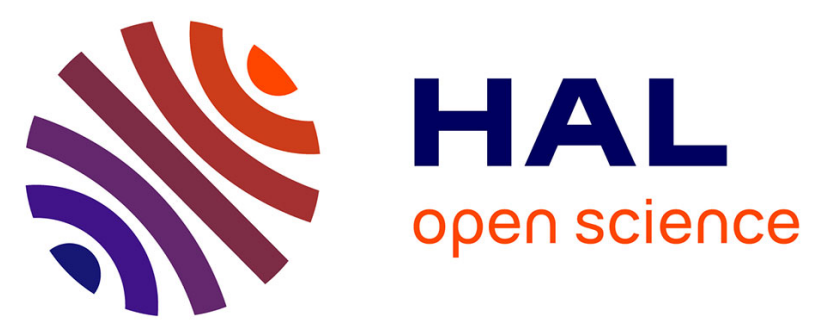

\title{
Thermotolerance, oxidative stress, apoptosis, heat-shock proteins and damages to reproductive cells of insecticide-susceptible and -resistant strains of the diamondback moth Plutella xylostella
}

\author{
L. J. Zhang, J. L. Chen, B. L. Yang, X. G. Kong, Denis Bourguet, G. Wu
}

\section{To cite this version:}

L. J. Zhang, J. L. Chen, B. L. Yang, X. G. Kong, Denis Bourguet, et al.. Thermotolerance, oxidative stress, apoptosis, heat-shock proteins and damages to reproductive cells of insecticide-susceptible and -resistant strains of the diamondback moth Plutella xylostella. Bulletin of Entomological Research, 2017, 107 (4), pp.513 - 526. 10.1017/S0007485317000049 . hal-01602587

\section{HAL Id: hal-01602587 \\ https://hal.science/hal-01602587}

Submitted on 23 Jul 2020

HAL is a multi-disciplinary open access archive for the deposit and dissemination of scientific research documents, whether they are published or not. The documents may come from teaching and research institutions in France or abroad, or from public or private research centers.
L'archive ouverte pluridisciplinaire HAL, est destinée au dépôt et à la diffusion de documents scientifiques de niveau recherche, publiés ou non, émanant des établissements d'enseignement et de recherche français ou étrangers, des laboratoires publics ou privés. 


\title{
Thermotolerance, oxidative stress, apoptosis, heat-shock proteins and damages to reproductive cells of insecticide-susceptible and -resistant strains of the diamondback moth Plutella xylostella
}

\author{
L.J. Zhang ${ }^{1}$, J.L. Chen ${ }^{1}$, B.L. Yang ${ }^{1}$, X.G. Kong ${ }^{1}$, \\ D. Bourguet ${ }^{2 *}+$ and G. Wu ${ }^{1 *}+$ \\ ${ }^{1}$ Key Laboratory of Biopesticide and Chemical Biology (Ministry of \\ Education), Fujian Agriculture and Forestry University, Fuzhou 350002, \\ China: ${ }^{2}$ Inra, UMR CBGP (Centre de Biologie pour la Gestion des \\ Populations), Montferrier-sur-Lez, France
}

\begin{abstract}
In this study, we investigated thermotolerance, several physiological responses and damage to reproductive cells in chlorpyrifos-resistant (Rc) and -susceptible (Sm) strains of the diamondback moth, Plutella xylostella subjected to heat stress. The chlorpyrifos resistance of these strains was mediated by a modified acetylcholinesterase encoded by an allele, ace1R, of the ace 1 gene. Adults of the Rc strain were less heat resistant than those of the Sm strain; they also had lower levels of enzymatic activity against oxidative damage, higher reactive oxygen species contents, weaker upregulation of two heat shock protein ( $h s p)$ genes (hsp69s and $h s p 20)$, and stronger upregulation of two apoptotic genes (caspase-7 and -9). The damage to sperm and ovary cells was greater in Rc adults than in Sm adults and was temperature sensitive. The lower fitness of the resistant strain, compared with the susceptible strain, is probably due to higher levels of oxidative stress and apoptosis, which also have deleterious effects on several life history traits. The greater injury observed in conditions of heat stress may be due to both the stronger upregulation of caspase genes and weaker upregulation of $h s p$ genes in resistant than in susceptible individuals.
\end{abstract}

Keywords: thermotolerance, chlorpyrifos, sperm and ovary cells, hsps genes, apoptotic genes, Plutella xylostella, cost of resistance, insecticide resistance

(Accepted 13 December 2016; First published online 31 January 2017)

\section{Introduction}

In all species, exposure to high temperatures is stressful and potentially lethal. As temperatures increase, insects display various physiological responses (Colinet et al., 2015).

*Author for correspondence

Phone: +86059183769631

Fax: +86059183789460

E-mail: newugang@163com

Phone: +33 499623366

Fax: +33 499623345

E-mail: denis.bourguet@inrae.fr

†These authors contributed equally to this work. These responses are often associated with an increase in the production of free radicals and reactive oxygen species (ROS), leading to significant physiological and structural damage. This damage, including the oxidation of proteins, enzymes and DNA, lipid peroxidation and glutathione depletion, has been observed in several species (e.g. Scapharca broughtonii (An \& Choi, 2010), Panonychus citri (Yang et al., 2010) and Aspergillus niger (Abrashev et al., 2008)). 


\section{L.J. Zhang et al.}

Insects have an antioxidant defense system to reduce the oxidative stress caused by ROS. This system involves several enzymes, including superoxide dismutase (SOD), catalase (CAT), glutathione-S-transferase (GST) and peroxidase (POD) (Barbehenn, 2002; Jia et al., 2011; Fahmy, 2012). For example, when subjected to heat stress, the oriental fruit fly, Bactrocera dorsalis, displays significant increases in lipid peroxide levels and in the activities of SOD, CAT and GST, providing protection against oxidative damage due to ROS (Jia et al., 2011).

Heat-shock proteins (HSPs) also play an important role in the response to heat stress (Nover \& Scharf, 1997; King \& MacRae, 2015). Indeed, the production of these proteins during periods of cellular stress increases the tolerance of heat and other stresses. The production of HSPs is, thus, a key survival strategy used by many organisms during exposure to high temperatures. HSPs can be classified into several families on the basis of their molecular mass and function: small HSPs (20-40 kD), HSP60, HSP70, HSP90 and HSP110 (Parsell \& Lindquist, 1993). The cytoplasmic HSP70 family is the most conserved of these families and has been studied extensively in the context of thermal stress (Krebs \& Feder, 1997; Bahrndorff et al., 2009; Calabria et al., 2012). This family includes two types of proteins with different expression profiles (Karlin \& Brocchieri, 1998; Rinehart et al., 2000; Mahroof et al., 2005). The first, inducible HSP70, is produced in small amounts in normal conditions but is rapidly induced by heat shock and other environmental stresses. The other, the cognate heat-shock 70 protein (HSC70), is constitutively expressed under normal conditions and slightly upregulated in response to heat stress (Kiang \& Tsokos, 1998; Mahroof et al., 2005; Daugaard et al., 2007).

Like many other cellular stresses, heat stress can trigger apoptosis, a physiological cell suicide program (Chowdhury et al., 2006). Apoptosis may involve several pathways, but the principal apoptotic pathway is that associated with mitochondria (Cullen \& Martin, 2009). This pathway, which can be induced by ROS (Circu \& Aw, 2010), involves several proteins, including cytochrome $c$, apoptotic protease activating factor-1 (Apaf-1), procaspase-9 (all of which are involved in transducing the apoptotic signal of the apoptosome) and caspases (Chowdhury et al., 2006). The caspases involved include the initiator caspases involved in upstream regulatory events, and the effector caspases (the executioners of apoptosis) directly responsible for disassembling the cell (Chang \& Yang, 2000). Briefly, heat stress induces the release of cytochrome $c$ from the mitochondria into the cytosol, where it binds Apaf-1. This binding triggers the cleavage of procaspase- 9 to generate the active initiator caspase- 9 , which activates the effector caspases, including caspases-3 and -7. These effector caspases execute the apoptosis program via the downstream caspase cascade and play a critical role in the final death of the cell (Chang \& Yang, 2000).

The diamondback moth (DBM) is probably the most destructive and cosmopolitan insect pest of cruciferous crops worldwide (Furlong et al., 2013), and it has become a model pest for studying insecticide resistance. In Chinese populations, resistance to several organophosphate (OP) insecticides is conferred by a single resistance allele, ace $1 R$, of the ace 1 gene, which encodes the acetylcholinesterase enzyme targeted by these OPs (Zhang et al., 2015a). The ace $1 R$ allele is characterized by two tightly linked mutations - A201S and G227A - affecting the amino acid sequence of the acetylcholinesterase enzyme (Zhang et al., 2015a). Our previous studies of DBM have shown that, under heat stress, individuals of a resistant strain (i.e. individuals heterozygous or homozygous for the ace1R allele) have lower pupal survival rates (Zhang et al., 2015b), adult emergence rates (Zhang et al., 2015b), adult longevity (Zhang et al., 2015a) and fertility (Zhang et al., 2015a) and greater damage to the wing veins (Liu et al., 2008; Zhang et al., 2015b) than individuals of a related susceptible strain. In terms of physiological effects, individuals of this resistant strain have higher basal levels of expression for several $h s p$ genes, and for the Apaf-1 and caspase-7 genes than susceptible individuals (Zhang et al., 2015b). They are also characterized by the weaker upregulation of several $h s p$ genes (Liu et al., 2008; Zhang et al., 2015b,c), and stronger upregulation of the caspase-7 (Zhang et al., 2011, 2015b) caspase-9 (Zhang et al., 2015b) and Apaf-1 (Zhang et al., 2014, 2015b) genes at high temperature.

We further explored the lower fitness of this resistant strain, its sensitivity to heat stress and the underlying physiological processes. We compared an additional life history trait, mortality, between adults of the resistant and susceptible strains exposed to different temperatures. We also compared the level of damage to sperm and ovary cells between individuals of these two strains, and focused on three physiological aspects: oxidative stress, apoptosis and HSPs.

\section{Materials and methods}

\section{Strains of Plutella xylostella}

We used two strains of $P$. xylostella: the Sm strain, which is mostly susceptible to chlorpyrifos, and the Rc strain, which displays a high level of resistance to this insecticide. These strains were obtained from a population collected close to Shangjie $\left(34^{\circ} 480 \mathrm{~N}, 113^{\circ} 180 \mathrm{E}\right)$, around Fuzhou (Fujian region, China), in November 2005. Details of the selection of these two strains are provided elsewhere (Zhang et al., 2015a). The $\mathrm{LC}_{50}$ of chlorpyrifos in the Rc strain was $2769 \mu \mathrm{g} \mathrm{l}{ }^{-1}$, indicating a susceptibility to this chemical 100 times lower than that in the Sm strain. The frequency of the resistance allele of ace1 - the gene encoding the acetylcholinesterase targeted by chlorpyrifos - differed between the Sm (frequency of 0.15) and Rc (frequency of 0.85) strains (Zhang et al., 2015a).

\section{Thermotolerance in adults}

Rc and Sm larvae were reared at $25^{\circ} \mathrm{C}$ with a photoperiod of $16 \mathrm{~h}$ light: $8 \mathrm{~h}$ dark until emergence of the adults. Four to eight hours after emergence, virgin males and virgin females were transferred to $25,30,35$ or $40^{\circ} \mathrm{C}$ conditions, and mortality rates were recorded after 24,48 and $72 \mathrm{~h}$. Adults that did not respond to prodding with a pencil tip were considered to be dead. For each strain, sex and temperature considered, we used three replicates, with 100 female or male adults per replicate.

\section{Damage to sperm and ovary cells}

Sm and Rc were exposed, 4-8 h after emergence, to temperatures of $25,30,35$ and $40^{\circ} \mathrm{C}$ for 24,48 and $72 \mathrm{~h}$ with a photoperiod of $16 \mathrm{~h}$ light: $8 \mathrm{~h}$ dark. Experiments were performed in insect environmental chambers (Experimental instrument Co., Ltd., Haishu Saifu, Ningbo, Zhejiang, China). Regardless the temperature and duration of the experiment, adults were supplied with sugar solution. For each strain and [temperature $\times$ duration] treatment, we used four 
replicates of at least 20 males and ten females. After treatment, a pair of spermaries was extracted from each treated male and immediately placed in liquid nitrogen. The ovaries of each treated female were also dissected and homogenized in physiological saline (see below). Damage to sperm or ovary cells was assessed in the single-cell gel electrophoresis (SCGE) assay (Singh et al., 1988).

\section{Sperm cells}

For each replicate of each [temperature $\times$ duration] treatment, a mixture of 15-20 pairs of spermaries was thawed and resuspended in Grace's medium containing 10\% dimethyl sulfoxide $(\mathrm{v}: \mathrm{v}=1: 1)$. The resulting mixture was used for at least ten SCGE experiments, providing at least ten slides of sperm cells for analysis. For each SCGE experiment, an aliquot of $15 \mu \mathrm{l}$ of the suspension of spermaries was mixed with $110 \mu \mathrm{l}$ of $0.5 \%$ low-melting point agarose (Sangon Ciotech, Ltd., Shanghai, China). This mixture was allowed to solidify and undergo protein degradation. Three layers of agarose gel were then prepared: two layers of $1 \%$ normal-melting point agarose (Sangon Ciotech, Ltd., Shanghai, China) separated by a layer of $0.8 \%$ low-melting point agarose containing the dried mixture of sperm cells. The three-layered gel was used for horizontal electrophoresis and stained. From the ten slides of sperm cells, we selected 50 cells at random, under a fluorescence microscope (at $400 \times$ magnification) for examination as described below. There were four replicates, resulting in the examination of 200 sperm cells in total for each [temperature $\times$ duration] treatment.

\section{Ovary cells}

For each replicate of each [temperature $\times$ duration] treatment, the ovaries extracted from ten females were mixed and resuspended in $0.5 \mathrm{ml}$ of physiological saline. This mixture was used immediately, for at least ten SCGE experiments, thus providing at least ten ovary cell slides for analysis. For each SCGE run, the first layer of agarose gel was prepared with $100 \mu \mathrm{l}$ of $1 \%$ normal-melting point agarose and covered with a coverslip during solidification. The coverslip was removed after $20 \mathrm{~min}$ and a $10 \mu \mathrm{l}$ aliquot of the ovary mixture, containing $0.8 \%$ low-melting point agarose, was then dispensed onto the first layer of agarose. It was covered with a coverslip for $20 \mathrm{~min}$. The coverslip was then removed and the third layer of low-melting point agarose was then added on top of the second layer and covered with a coverslip for $20 \mathrm{~min}$. The coverslip was removed and the three-layered gel was immersed in a lysis solution $(2.5 \mathrm{M} \mathrm{NaCl}, 100 \mathrm{mM}$ EDTA, $1 \%$ Triton $\mathrm{X}-100,1 \%$ sarkosyl, $10 \%$ DMSO, 10 mM Tris, $\mathrm{pH} 10$, supplemented with $0.06 \mathrm{mg} \mathrm{ml}^{-1}$ proteinase $\mathrm{K}$ ) for $3 \mathrm{~h}$ to degrade the proteins. The gel was used for horizontal electrophoresis in a cold alkaline electrophoresis buffer $(12.3 \mathrm{~g}$ sodium acetate, $6.1 \mathrm{~g}$ Tris and $18.6 \mathrm{~g} \mathrm{Na} \mathrm{NDDTA}_{2}$ in $500 \mathrm{ml}$ $\mathrm{H}_{2} \mathrm{O}, \mathrm{pH} 10$ ) for $40 \mathrm{~min}$ at $4^{\circ} \mathrm{C}, 20 \mathrm{~V}$ and $200 \mathrm{~mA}$. After electrophoresis, the gel was washed with fresh neutralization buffer (0.4 M Tris-HCL at pH 7.0) to remove any remaining alkali and detergent and was then immersed in a staining solution (SYBR Green I diluted 1:10,000 in TBE buffer) for $15 \mathrm{~min}$. We randomly selected 20-410 cells from the ten slides of ovary cells for examination under a fluorescence microscope (at $10 \times$ magnification), as indicated below. Hence, with four replicates, we examined between 88 and 1621 ovary cells per [temperature $\times$ duration] treatment.

\section{Cell analyses}

The images of each of the selected sperm and ovary cells were captured with an Olympus fluorescence microscope and analyzed with Comet Assay software (Konca et al., 2003). This software made use of two parameters to determine cell damage: (1) the percentage of damaged cells, calculated as the number of cells without a comet tail/total number of cells observed, multiplied by 100 and (2) comet tail length, estimated from the image as the length of the tail from the nuclear region to its end. For ovary cells, an additional parameter was included: tail moment, determined as tail length $\times$ the fraction of total DNA in the tail. Overall, the treatments and replicates resulted in the analysis of 2400 sperm cells for both Rc and Sm, and 5485 and 3530 ovary cells for Rc and Sm, respectively.

\section{Enzyme assays and ROS levels}

\section{Heat stress in adults}

Levels of SOD (EC 1.1.5.1.1), CAT (EC 1.11.1.6) and POD (EC 1.11.1.7) activity and of ROS were measured in adults after exposure to temperatures of $25,33.5,37$ and $42^{\circ} \mathrm{C}$ for 1 , $8,24,48$ and $72 \mathrm{~h}$, respectively.

\section{Preparation of enzyme extracts}

For each DBM strain and each enzyme, three replicate enzyme extracts were used. For each replicate, ten adults were homogenized at $0^{\circ} \mathrm{C}$ in $50 \mathrm{mM}$ sodium phosphate buffer ( $\mathrm{pH}$ 7.0) and then centrifuged at $12,000 \times g$ and $4^{\circ} \mathrm{C}$ for 20 min. The supernatants were used to determine SOD, CAT and POD activities.

\section{Preparation of extracts for the measurement of ROS levels}

For each DBM strain, we performed three replicates. For each replicate, ten adults were homogenized at $0^{\circ} \mathrm{C}$ in 65 $\mathrm{mM}$ sodium phosphate buffer $(\mathrm{pH} 7.8)$ and centrifuged at $5000 \times \mathrm{g}$ and $4^{\circ} \mathrm{C}$ for $20 \mathrm{~min}$. The supernatants obtained were used for the determination of ROS levels. Protein concentration was determined by the method of Bradford (1976), with bovine serum albumin as the standard.

\section{Enzymatic activity}

SOD activity was determined by the pyrogallol autooxidation method (Marklund \& Marklund, 1974). The reaction mixture $(4.5 \mathrm{ml})$ contained sodium phosphate buffer $(\mathrm{pH} 8.3$, final concentration $50 \mathrm{mM}$ ), pyrogallol (final concentration $0.02 \mathrm{mM}$ ) and $10 \mu \mathrm{l}$ of enzyme extract. The absorbance of the mixture was measured at $325 \mathrm{~nm}$, every $30 \mathrm{~s}$ for $3 \mathrm{~min}$, at $25^{\circ} \mathrm{C}$. One unit (U) of SOD corresponded to the amount of enzyme required to inhibit pyrogallol auto-oxidation by $50 \%$ in $4.5 \mathrm{ml}$ of assay mixture at $25^{\circ} \mathrm{C}$. SOD activity $\left(\mathrm{U} \mathrm{mg}^{-1}\right.$ protein $)=$ $\left[\left(0.07-\Delta \mathrm{A}_{325} \mathrm{~min}^{-1}\right)\right] \times 100 \% /[0.07 \times 50 \% \times \mathrm{mg}$ protein $]$.

CAT activity was measured as described by Liu \& Wu (2006). The reaction mixture $(5 \mathrm{ml})$ contained sodium phosphate buffer ( $\mathrm{pH} 7.0$, final concentration $50 \mathrm{mM}$ ), $\mathrm{H}_{2} \mathrm{O}_{2}$ (final concentration $8 \mathrm{mM}$ ) and $100 \mu \mathrm{l}$ of enzyme extract. The reaction was conducted at $30^{\circ} \mathrm{C}$ for $1 \mathrm{~min}$ and was stopped by adding $2 \mathrm{ml} 10 \% \mathrm{H}_{2} \mathrm{SO}_{4}$. The absorbance of the mixture was measured at $240 \mathrm{~nm}$, every $30 \mathrm{~s}$ for $5 \mathrm{~min}$, at $30^{\circ} \mathrm{C}$. CAT activity is expressed as $\Delta \mathrm{A}_{240} \mathrm{~min}^{-1} \times \mathrm{mg}^{-1}$ protein. 


\section{L.J. Zhang et al.}

POD activity was measured as described by Liu et al. (2007). The reaction mixture $(3 \mathrm{ml})$ consisted of sodium phosphate buffer ( $\mathrm{pH}$ 6.0, final concentration $100 \mathrm{mM}$ ), guaiol (final concentration $30 \mathrm{mM}$ ), $\mathrm{H}_{2} \mathrm{O}_{2}$ (final concentration 26 $\mathrm{mM}$ ) and $150 \mu \mathrm{l}$ of enzyme extract. The increase in absorbance at $470 \mathrm{~nm}$ and $30^{\circ} \mathrm{C}$ was recorded after adding $2 \mathrm{ml}$ of $20 \%$ chloroacetic acid. The specific activity of the enzyme is expressed as $\Delta \mathrm{A}_{470} \mathrm{~min}^{-1} \times \mathrm{mg}^{-1}$ protein.

\section{ROS levels}

The rate of $\mathrm{O}_{2}^{-}$production was assessed as described by Schneider \& Schlegel (1981). In the presence of superoxide radicals, hydroxylamine was oxidized to nitrite. The reaction mixture $(2 \mathrm{ml})$ consisted of $0.9 \mathrm{ml} 65 \mathrm{mM}$ sodium phosphate buffer (pH 7.8), $0.1 \mathrm{ml} 10 \mathrm{mM}$ hydroxylamine hydrochloride and $1 \mathrm{ml}$ of extract. The mixture was incubated at $25^{\circ} \mathrm{C}$ for $20 \mathrm{~min}$. Nitrite formation was assessed by $0.70 \mathrm{ml}$ each of 17 $\mathrm{mM}$ sulphanilic acid and $7 \mathrm{mM} \alpha$-naphthylamine to $0.70 \mathrm{ml}$ of reaction mixture. The mixture was incubated at $25^{\circ} \mathrm{C}$ for 20 min and absorbance at $530 \mathrm{~nm}$ was recorded. Nitrite concentration was determined by comparison with a standard curve. The rate of $\mathrm{O}_{2}^{-}$production is expressed as $\mathrm{nmol} \times \min ^{-1} \times$ $\mathrm{mg}^{-1}$ protein.

\section{Levels of mRNA for hsp and apoptosis-related genes}

\section{Heat stress in adults}

Before RNA extraction, individuals were exposed to different temperatures for various periods of time. Virgin adults developing from larvae reared at $25^{\circ} \mathrm{C}$, were exposed, $4-8 \mathrm{~h}$ after emergence, to a temperature of $40^{\circ} \mathrm{C}$ for 24,48 or $72 \mathrm{~h}$. Individuals were allowed to recover for $1 \mathrm{~h}$ at $25^{\circ} \mathrm{C}$ and were then frozen for RNA extraction.

\section{RNA extraction}

For each gene, we performed at least three independent RNA extractions. For each extraction, we obtained total RNA from 12 individuals with a simple total RNA extraction kit (Tiangen Biotech Co., Ltd., Beijing, China), and cDNA was synthesized from $1 \mu \mathrm{g}$ of total RNA with the SuperScript ${ }^{\mathrm{T}}$ II First-Strand System (Life Technologies, Carlsbad, California, USA).

\section{Real-time quantitative PCR ( $q P C R$ )}

We estimated mRNA levels for six heat shock protein genes (hsp genes) and four apoptotic genes connected to the mitochondrial pathway of apoptosis, identified by our research group in $P$. xylostella from Fujian, China. We also estimated mRNA levels for the $\beta$-actin gene, used as a reference gene. The $h s p$ genes included $h s p 69-3$ (encoding a protein with 629 amino acids (aa), GenBank number ADK94699.1), hsp69-4 (632 aa, ADK39311.1), hsp72-2 (669 aa, ADV58254.1), hsc70 (651 aa, JN676213), hsp90 (717 aa, KF471526) and hsp20 (174 aa, KF471527). The four mitochondrial apoptosis pathwayrelated genes studied were the cytochrome $c$ (cyt c; 108 aa, KC507801), Apaf-1 (1548 aa, KC588901), caspase-9 (451 aa, KF365914) and caspase-7 (300 aa, HM204505) genes. The primers used for qPCR were designed from the conserved regions of the genes (Table S1).
The mRNA levels of these $h s p$ and mitochondria-associated apoptotic pathway genes were estimated by real-time qPCR using SYBR Premix Ex TaqTM kit (Takara Co., Dalian, China) as described by Zhuang et al. (2011) and Zhang et al. $(2015 b)$. The thermal cycling conditions used were an initial DNA denaturation at $95^{\circ} \mathrm{C}$ for $10 \mathrm{~s}$ followed by 40 cycle of denaturation at $95^{\circ} \mathrm{C}$ for $6 \mathrm{~s}$, primer annealing at optimal temperature $60^{\circ} \mathrm{C}$ for $25 \mathrm{~s}$, and an additional incubation step at annealing temperature for $10 \mathrm{~s}$ to measure the SYBR Green fluorescence. Finally, melt curve analysis was performed by slowly thermaling the PCR products from 70 to $95^{\circ} \mathrm{C}\left(0.2^{\circ} \mathrm{C}\right.$ per cycle hold $2 \mathrm{~s}$ ) with simultaneous measurement of the SYBR Green signal intensity. Relative mRNA expression of hsps and mitochondria-associated apoptotic pathway genes was measured to the housekeep gene $\beta$-actin, which was amplified by PCR using primers $\beta$-actin-F and $\beta$-actin-R (Table S1). The transcriptional level of inner-control was similar among different samples.

For all genes, the mean normalized expression was calculated by comparing the threshold cycle of these genes to that of $\beta$-actin gene according to the equations of standard curves in the target genes and the reference gene (Larionov et al., 2005). The standard curves of target genes and reference gene were made using ten times serial dilutions with six different cDNA concentrations. The mRNA expression was replicated on at least three biological replicates with 12 insect individuals in each replication.

\section{Statistical analysis}

We used Fisher exact tests and post hoc pairwise Fisher's exact tests to compare the percentages of ovary and sperm cells damages. Means (for mortality rates, comet tail lengths, tail moments, transcription levels and enzyme activities) were compared either using Dunn's tests of multiple comparisons using rank sums and applying a false discovery rate. All statistical analyses were conducted using the software R version 3.2.0 (R Development Core Team, 2015).

\section{Results \\ Thermotolerance}

At 25 and $30^{\circ} \mathrm{C}$, mortality was very low for both strains $(\leq 1.3 \%)$ regardless of the duration of heat treatment (Table 1). The exposure of adults to temperatures of 35 and $40^{\circ} \mathrm{C}$ led to an increase in the mortality of both males and females to a maximum of about 23\% (for males) and 73\% (for females) after $72 \mathrm{~h}$ at $40^{\circ} \mathrm{C}$ (Table 1). Males were significantly more heat tolerant than females, with female mortality generally twice that for males (Table 1). Finally, with few exceptions, the males and females of the resistant strain (Rc) had a higher mortality than those of the susceptible strain (Sm). At all temperatures and for all durations of treatment, adults of the Rc strain generally had a heat tolerance about half that of the $\mathrm{Sm}$ strain, and this difference in survival was significant after $72 \mathrm{~h}$ at $35^{\circ} \mathrm{C}$ for females and after 48 and $72 \mathrm{~h}$ at $40^{\circ} \mathrm{C}$ for both males and females (Table 1).

\section{Damage to sperm and ovary cells}

The percentage of damaged sperm and ovary cells increased with temperature and, for a given temperature, with the duration of exposure of the males and females (Tables 2 
Lower fitness and physiological impact in a DBM resistant strain

Table 1. Male and female adult mortality rates of the Sm and Rc strains exposed to different temperatures.

\begin{tabular}{|c|c|c|c|c|c|}
\hline \multirow[b]{2}{*}{ Sex } & \multirow[b]{2}{*}{ Temp. $\left({ }^{\circ} \mathrm{C}\right)$} & \multirow[b]{2}{*}{ Strain } & \multicolumn{3}{|c|}{$\%$ Mortality $($ mean \pm SD) } \\
\hline & & & After $24 \mathrm{~h}$ & After $48 \mathrm{~h}$ & After $72 \mathrm{~h}$ \\
\hline \multirow[t]{5}{*}{ Males } & 25 & Sm & 0 & $0.33 \pm 0.58 a$ & $0.33 \pm 0.58 \mathrm{a}$ \\
\hline & 30 & Sm & 0 & $0.67 \pm 0.58 \mathrm{a}$ & $1.00 \pm 1.00 \mathrm{a}$ \\
\hline & & Rc & $0.33 \pm 0.58 a$ & $0.67 \pm 0.58 a$ & $1.00 \pm 1.00 \mathrm{a}$ \\
\hline & 35 & $\mathrm{Sm}$ & $1.67 \pm 0.58 b$ & $3.00 \pm 1.00 \mathrm{a}, \mathrm{b}$ & $3.67 \pm 0.58 \mathrm{a}, \mathrm{b}$ \\
\hline & & Rc & $2.33 \pm 0.58 b, c$ & $3.67 \pm 0.58 b$ & $5.33 \pm 0.58 b$ \\
\hline \multirow[t]{6}{*}{ Females } & 25 & $\mathrm{Sm}$ & 0 & $0.33 \pm 0.58 \mathrm{a}$ & $0.33 \pm 0.58 a$ \\
\hline & & Rc & 0 & $0.33 \pm 0.58 a$ & $0.33 \pm 0.58 a$ \\
\hline & 30 & Sm & $0.67 \pm 0.58 \mathrm{a}$ & $0.33 \pm 0.58 \mathrm{a}$ & $1.00 \pm 1.00 \mathrm{a}$ \\
\hline & & Rc & $0.33 \pm 0.58 \mathrm{a}$ & $0.33 \pm 0.58 \mathrm{a}$ & $1.33 \pm 0.58 \mathrm{a}$ \\
\hline & 35 & Sm & $2.67 \pm 1.15 \mathrm{ab}$ & $4.33 \pm 0.58 b$ & $7.00 \pm 2.00 \mathrm{ab}$ \\
\hline & & $\mathrm{Rc}$ & $3.67 \pm 1.15 b$ & $5.00 \pm 1.00 \mathrm{~b}$ & $13.00 \pm 2.00 b$ \\
\hline
\end{tabular}

Notes: Temp. corresponds to temperature. For each sex and at each duration of treatment, means followed by different letters were significantly different (Dunn's tests, $P \leq 0.05$ ).

Table 2. Comet tail length of sperm cells in adult males of the Sm and Rc strains exposed at different temperatures during different durations of exposure.

\begin{tabular}{|c|c|c|c|c|c|}
\hline $\begin{array}{l}\text { Temp. } \\
\left({ }^{\circ} \mathrm{C}\right)\end{array}$ & $\begin{array}{l}\text { Duration } \\
\text { (h) }\end{array}$ & Strain & $N$ & $\begin{array}{l}\% \text { damaged } \\
\text { cells }\end{array}$ & $\begin{array}{l}\text { Comet tail } \\
\text { length in } \mu \mathrm{m} \\
(\text { mean } \pm S D)\end{array}$ \\
\hline \multirow[t]{6}{*}{25} & \multirow[t]{2}{*}{24} & $\mathrm{Sm}$ & 200 & $0.50 \mathrm{a}$ & $1.12 \pm 0.06 a$ \\
\hline & & Rc & 200 & $0.50 \mathrm{a}$ & $1.22 \pm 0.04 \mathrm{a}$ \\
\hline & \multirow[t]{2}{*}{48} & $\mathrm{Sm}$ & 200 & $0.50 \mathrm{a}$ & $2.12 \pm 0.12 b$ \\
\hline & & Rc & 200 & $0.50 \mathrm{a}$ & $1.94 \pm 0.06 b c$ \\
\hline & \multirow[t]{2}{*}{72} & $\mathrm{Sm}$ & 200 & $0.50 \mathrm{a}$ & $2.05 \pm 0.23 b c$ \\
\hline & & Rc & 200 & $0.50 \mathrm{a}$ & $1.88 \pm 0.13 c$ \\
\hline \multirow[t]{6}{*}{30} & \multirow[t]{2}{*}{24} & $\mathrm{Sm}$ & 200 & $1.00 \mathrm{a}$ & $2.54 \pm 0.13 a$ \\
\hline & & Rc & 200 & $0.50 \mathrm{a}$ & $2.61 \pm 0.15 a$ \\
\hline & \multirow[t]{2}{*}{48} & Sm & 200 & $0.50 \mathrm{a}$ & $2.24 \pm 0.22 \mathrm{a}$ \\
\hline & & Rc & 200 & $1.00 \mathrm{a}$ & $2.52 \pm 0.31 a$ \\
\hline & \multirow[t]{2}{*}{72} & Sm & 200 & $1.00 \mathrm{a}$ & $2.34 \pm 0.42 a$ \\
\hline & & Rc & 200 & $1.50 \mathrm{a}$ & $2.32 \pm 0.21 \mathrm{a}$ \\
\hline \multirow[t]{6}{*}{35} & \multirow[t]{2}{*}{24} & Sm & 200 & $4.00 \mathrm{a}$ & $14.75 \pm 0.26 a$ \\
\hline & & Rc & 200 & $5.00 \mathrm{a}$ & $15.32 \pm 0.33 b$ \\
\hline & \multirow[t]{2}{*}{48} & Sm & 200 & $6.00 \mathrm{a}$ & $16.62 \pm 0.14 c$ \\
\hline & & Rc & 200 & $7.50 \mathrm{a}$ & $18.42 \pm 0.24 \mathrm{~d}$ \\
\hline & \multirow[t]{2}{*}{72} & Sm & 200 & $8.00 \mathrm{a}$ & $20.44 \pm 0.16 \mathrm{e}$ \\
\hline & & Rc & 200 & $10.00 \mathrm{a}$ & $21.42 \pm 0.54 \mathrm{f}$ \\
\hline \multirow[t]{6}{*}{40} & \multirow[t]{2}{*}{24} & $\mathrm{Sm}$ & 200 & $7.00 \mathrm{a}$ & $21.92 \pm 0.14 \mathrm{a}$ \\
\hline & & Rc & 200 & $8.00 \mathrm{a}$ & $22.21 \pm 0.22 \mathrm{a}$ \\
\hline & \multirow[t]{2}{*}{48} & $\mathrm{Sm}$ & 200 & $9.00 \mathrm{a}$ & $24.92 \pm 0.35 b$ \\
\hline & & Rc & 200 & $10.00 \mathrm{a}$ & $26.35 \pm 0.45 c$ \\
\hline & \multirow[t]{2}{*}{72} & $\mathrm{Sm}$ & 200 & $11.00 \mathrm{a}$ & $25.35 \pm 0.22 b$ \\
\hline & & Rc & 200 & $13.00 \mathrm{a}$ & $29.66 \pm 0.35 d$ \\
\hline
\end{tabular}

Notes: Temp. corresponds to temperature and $N$ corresponds to the number of sperm cells observed. For each temperature, \% of damaged cells and mean comet tail length followed by different letters were significantly different $(P \leq 0.05)$ (Fisher exact tests and Dunn's tests, respectively).

and 3 and fig. 1). Regardless the duration of exposure, the percentages of damaged cells remained low $(\leq 10 \%)$ at 25,30 and $35^{\circ} \mathrm{C}$. At these temperatures, the percentages of damaged cells did not differ significantly between susceptible and resistant adults. Following the exposure of females to a temperature of $40^{\circ} \mathrm{C}$ for at least $48 \mathrm{~h}$, the level of damage to ovary cells was found to be significantly higher in Rc (26-27\%) than in Sm $(6-7 \%)$ females (Table 3$)$. At $40^{\circ} \mathrm{C}$, the percentage of damaged sperm cells was also higher for Rc males than for Sm males (11 versus $13 \%$ after $72 \mathrm{~h}$ ), but this difference was not significant (Table 3).

For both types of cells, the length of the comet tail strongly increased with the temperature and duration of exposure (see Tables 2 and 3 for sperm and ovary cells, respectively). After 48 and $72 \mathrm{~h}$ of exposure to temperatures of 35 and $40^{\circ} \mathrm{C}$, the comet tails of the sperm and ovary cells were always longer in Rc than in Sm adults. For both sperm and ovary cells, this difference in length became significant after 48 and $72 \mathrm{~h}$ of exposure to a temperature of $40^{\circ} \mathrm{C}$ (Tables 2 and 3). After $72 \mathrm{~h}$ of exposure to a temperature of $40^{\circ} \mathrm{C}$, the comet tail of the sperm cells was 17\% shorter in Sm than in Rc males and that of the ovary cells was $29 \%$ shorter in Sm than in Rc females.

Finally, the tail moment of ovary cells was always greater in Rc than in Sm females, but this difference was significant only after $72 \mathrm{~h}$ of exposure to a temperature of $40^{\circ} \mathrm{C}$ (Table 3 ).

\section{SOD, CAT, POD activities and ROS contents}

At $25^{\circ} \mathrm{C}$, adults of the Sm strain had significantly higher SOD, CAT and POD activities and lower ROS contents than those of the Rc strain. No significant differences in SOD, CAT and POD activities or ROS content were found after exposure to a temperature of $25^{\circ} \mathrm{C}$ for $1-72 \mathrm{~h}$ (fig. 2 and Table S2). By contrast, significant increases in SOD, CAT and POD activities and ROS content were found in both Rc and Sm adults exposed to temperatures of $33.5,37$ and $42^{\circ} \mathrm{C}$ for $1,8,24,48$ and $72 \mathrm{~h}$ (fig. 2 and Table S2). However, the profiles of enzyme activity or ROS content increase varied with the enzyme, temperature or duration of exposure considered. The activities of SOD and POD reached a plateau after 8-48 h, but then declined significantly after $72 \mathrm{~h}$ of exposure to temperatures of $33.5,37$ and $42^{\circ} \mathrm{C}$. CAT activity changed little in response to exposure between 1 and $72 \mathrm{~h}$ to temperatures of $33.5,37$ and 


\section{L.J. Zhang et al.}

Table 3. Comet tail length and tail moment of ovary cells in adult females of the Sm and Rc strains exposed at different temperatures during different durations of exposure.

\begin{tabular}{|c|c|c|c|c|c|c|}
\hline Temp. $\left({ }^{\circ} \mathrm{C}\right)$ & Duration $(\mathrm{h})$ & Strain & $N$ & $\%$ damaged cells & Comet tail length in $\mu \mathrm{m}$ (mean \pm SD) & Tail moment (mean \pm SD) \\
\hline \multirow[t]{5}{*}{25} & \multirow[t]{2}{*}{24} & $\mathrm{Sm}$ & 255 & $2.35 a$ & $72.83 \pm 16.43 a$ & $8.98 \pm 4.93 a$ \\
\hline & & Rc & 788 & $1.40 \mathrm{a}$ & $71.82 \pm 16.36 a$ & $13.10 \pm 5.67 b c$ \\
\hline & 48 & $\mathrm{Sm}$ & 340 & $2.06 \mathrm{a}$ & $81.57 \pm 22.02 b$ & $12.31 \pm 7.14 \mathrm{c}$ \\
\hline & \multirow[t]{2}{*}{72} & Sm & 998 & $1.80 \mathrm{a}$ & $71.11 \pm 12.71 \mathrm{a}$ & $14.26 \pm 7.57 \mathrm{~b}$ \\
\hline & & Rc & 1621 & $3.02 \mathrm{a}$ & $84.98 \pm 22.08 c$ & $17.62 \pm 9.61 d$ \\
\hline \multirow[t]{4}{*}{35} & 24 & Sm & 107 & $2.80 \mathrm{a}$ & $71.00 \pm 18.52 \mathrm{a}$ & $4.16 \pm 1.94 \mathrm{a}$ \\
\hline & 48 & Rc & 92 & $3.26 a$ & $76.00 \pm 1.73 c$ & $12.63 \pm 1.36 \mathrm{c}$ \\
\hline & \multirow[t]{2}{*}{72} & Sm & 376 & $6.38 \mathrm{a}$ & $79.24 \pm 20.10 c$ & $16.80 \pm 10.77 \mathrm{db}$ \\
\hline & & Rc & 257 & $7.78 \mathrm{a}$ & $95.60 \pm 25.21 d$ & $19.73 \pm 12.15 \mathrm{~d}$ \\
\hline \multirow[t]{4}{*}{40} & \multirow[t]{2}{*}{24} & Sm & 170 & $5.29 \mathrm{a}$ & $71.22 \pm 16.16 a$ & $9.54 \pm 4.81 \mathrm{a}$ \\
\hline & & Rc & 721 & $3.88 \mathrm{a}$ & $79.07 \pm 19.71 b$ & $13.48 \pm 6.94 a$ \\
\hline & \multirow[t]{2}{*}{48} & Sm & 725 & $6.62 \mathrm{a}$ & $87.33 \pm 27.75 c$ & $16.83 \pm 13.35 \mathrm{ab}$ \\
\hline & & Rc & 755 & $27.41 \mathrm{~b}$ & $109.42 \pm 45.58 \mathrm{~d}$ & $23.92 \pm 19.23 c$ \\
\hline
\end{tabular}

Notes: Temp. corresponds to temperature and $N$ corresponds to the number of ovary cells observed. For each temperature, $\%$ of damaged cells in one hand and mean comet tail length and mean tail moment on the other hand followed by different letters were significantly different $(P \leq 0.05)$ (Fisher exact tests and Dunn's tests, respectively).

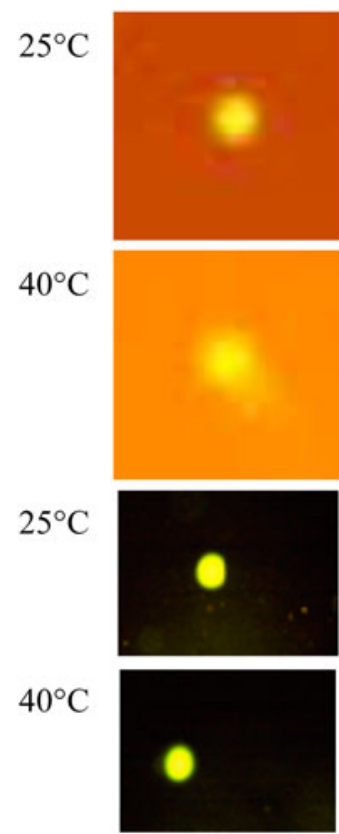

Sm for $24 \mathrm{~h}$
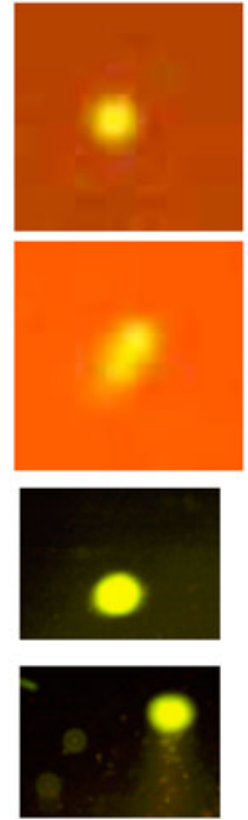

Rc for $24 \mathrm{~h}$
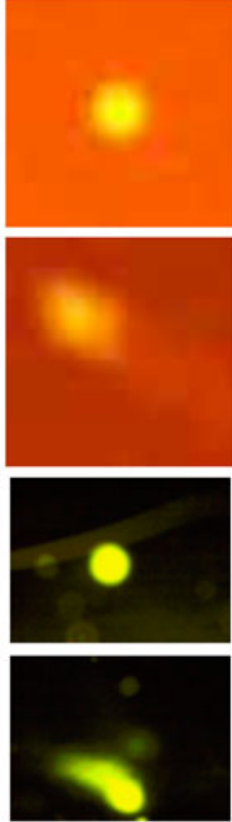

Sm for $72 \mathrm{~h}$
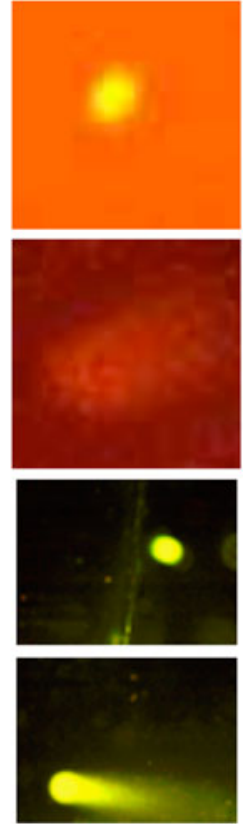

Rc for $72 \mathrm{~h}$

Fig. 1. Damages of sperm (upper two lines) and ovary (down two lines) cells in adults of the Rc and Sm strains exposed at 25 or $40^{\circ} \mathrm{C}$ for either 24 or $72 \mathrm{~h}$.

$42^{\circ} \mathrm{C}$. Finally, ROS levels increased gradually from 1 to $72 \mathrm{~h}$ of exposure to temperatures of $33.5,37$ and $42^{\circ} \mathrm{C}$. In general, for all temperatures and exposure times, adults from the Rc strain had significantly lower SOD, CAT and POD activities, and significantly higher ROS contents than those of the Sm strain (fig. 2 and Table S2).
Levels of mRNA for hsp/hsc and apoptosis-related genes

In general, at $25^{\circ} \mathrm{C}$, mRNA levels for $h s p$ ( $h s p 20, h s p 70 s$, $h s c 70$ and $h s p 90$ ) (fig. 3 and Table S3) and for apoptosis-related (cytochrome c, Apaf-1, caspases-9 and -7) (Table 4) genes remained constant over time. Transcription levels for these genes therefore remained essentially constant from emergence 

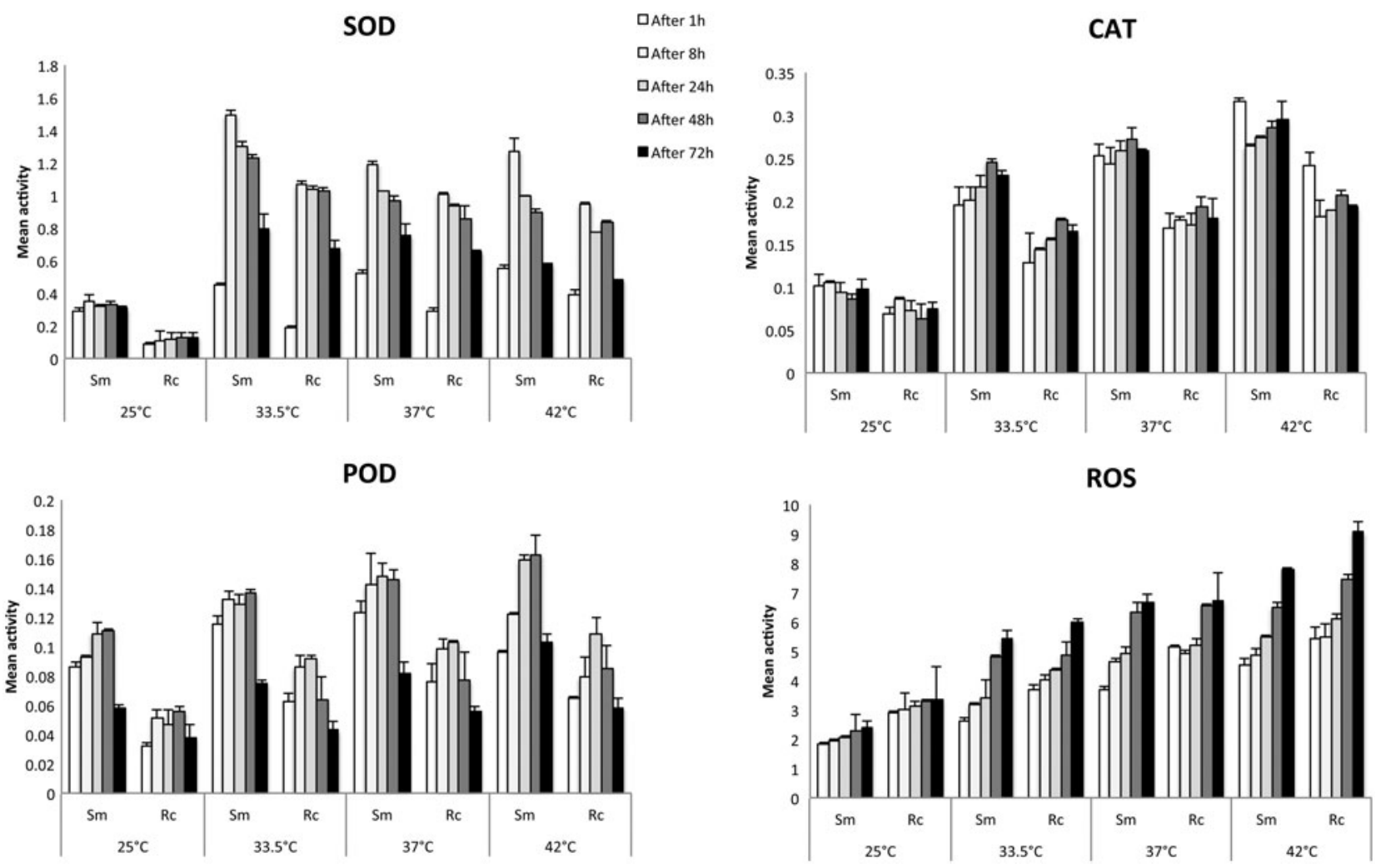

Fig. 2. Mean $( \pm S D)$ activities of SOD, CAT and POD and ROS contents in adults of the Rc and Sm strains exposed at different temperatures. For SOD, CAT, POD and ROS, activities are expressed as $\mathrm{U} \mathrm{mg}^{-1} \mathrm{~min}^{-1}, \Delta \mathrm{OD} 240 \mathrm{mg} \mathrm{min}^{-1}, \Delta \mathrm{OD} 470 \mathrm{mg} \mathrm{min}^{-1}$ and $\mathrm{nmol} \mathrm{mg} \mathrm{mg}^{-1}$ $\mathrm{min}^{-1}$, respectively. The exact mean values and the statistical comparisons between means are given in Table S2.

to $72 \mathrm{~h}$ after emergence. At $40^{\circ} \mathrm{C}$, a significant upregulation of the expression of all the $h s p$ and apoptosis-related genes was observed in both $\mathrm{Sm}$ and Rc adults. Conversely, in both strains, mRNA levels for $h s c 70$ were not significantly higher at $40^{\circ} \mathrm{C}$ than at $25^{\circ} \mathrm{C}$.

At $25^{\circ} \mathrm{C}$, the gene expressions of $h s p 20, h s p 69-2 a$ and cytochrome $c$ were significantly higher in Rc than in Sm adults (fig. 3, Table S3 and Table 4). The influence of heat stress on gene expression was significantly different in the two strains. For all but two of the $h s p$ genes ( $h s p 69-4$ and $h s p 90)$, the increase in mRNA levels at $40^{\circ} \mathrm{C}$ was significantly smaller in Rc than in $\mathrm{Sm}$ adults. For apoptosis-related genes, the increase in mRNA levels at $40^{\circ} \mathrm{C}$ was significantly smaller (for cytochrome $c$ and Apaf-1) or larger (for caspases-7 and -9) in Rc than in Sm individuals (Table 4).

\section{Discussion}

\section{Thermosensitivity}

Individuals of the susceptible and resistant strains of the DBM studied here differed in several life history traits. The traits affected include pupal survival rate, adult longevity, hatchability, wing structure, female fecundity and adult emergence rate, but a number of other traits appear to be unaffected (Table 5). Here, we explored adult mortality, an additional life history trait. As already reported in many other studies (Atwal, 1955; Yun et al., 2013), including some performed as long ago as 1917 by Marsh (1917), the mortality of adult
$\mathrm{DBM}$ at high temperatures (i.e. 35 and $40^{\circ} \mathrm{C}$ ) was much higher than that at more usual temperatures (i.e. 25 and $30^{\circ} \mathrm{C}$ ). More importantly, mortality was higher in the insecticide-resistant strain than in insecticide-susceptible strain. Indeed, at all temperatures and for all durations of treatment, adults of the resistant strain Rc were generally only half as heat tolerant as those of the susceptible strain Sm.

However, contrary to other life history traits, this difference was not temperature dependent. Indeed, we have recently shown (Zhang et al., 2015a,b) that the difference in several life history traits appeared (pupal survival rate, adult longevity, hatchability) or was magnified (female fecundity and adult emergence rate) at high temperature (Table 5). Like the degree of wing damage (Table 5), adult mortality was greater in resistant than in susceptible individuals even at temperatures favorable for development, but this difference did not increase at higher temperatures.

\section{Fecundity, fertility and damage to sperm and ovary cells}

Zhang et al. (2015a) and Liu et al. (2008) found that fecundity was about $20 \%$ lower in resistant females than in susceptible females at temperatures optimal for development, and that the relative fecundity of the resistant females decreased further at high temperatures. We show here that this temperature-sensitive decrease in fecundity may be due to greater damage to reproductive cells in resistant than in susceptible individuals. Indeed, at high temperatures (i.e. 35 


\section{L.J. Zhang et al.}
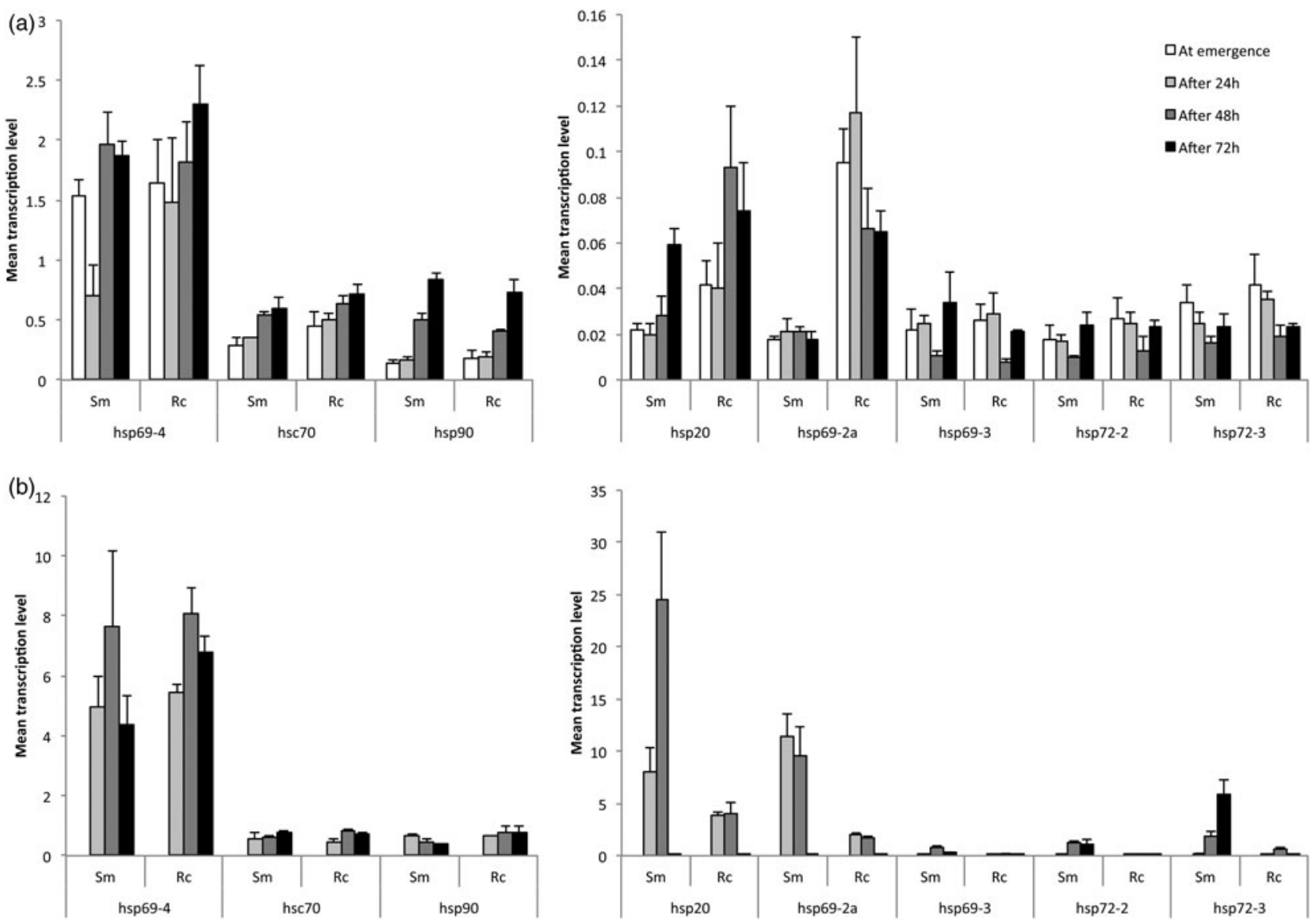

Fig. 3. Mean ( \pm SD) transcription levels of the $h s p / h s c$ genes in adults of the Rc and Sm strains exposed at 25 (a) and $40^{\circ} \mathrm{C}(\mathrm{b})$. The exact mean values and the statistical comparisons between means are given in Table S3.

Table 4. Transcription level of several key genes of the mitochondria associated apoptotic pathway in the Rc and Sm strains exposed at two different temperatures.

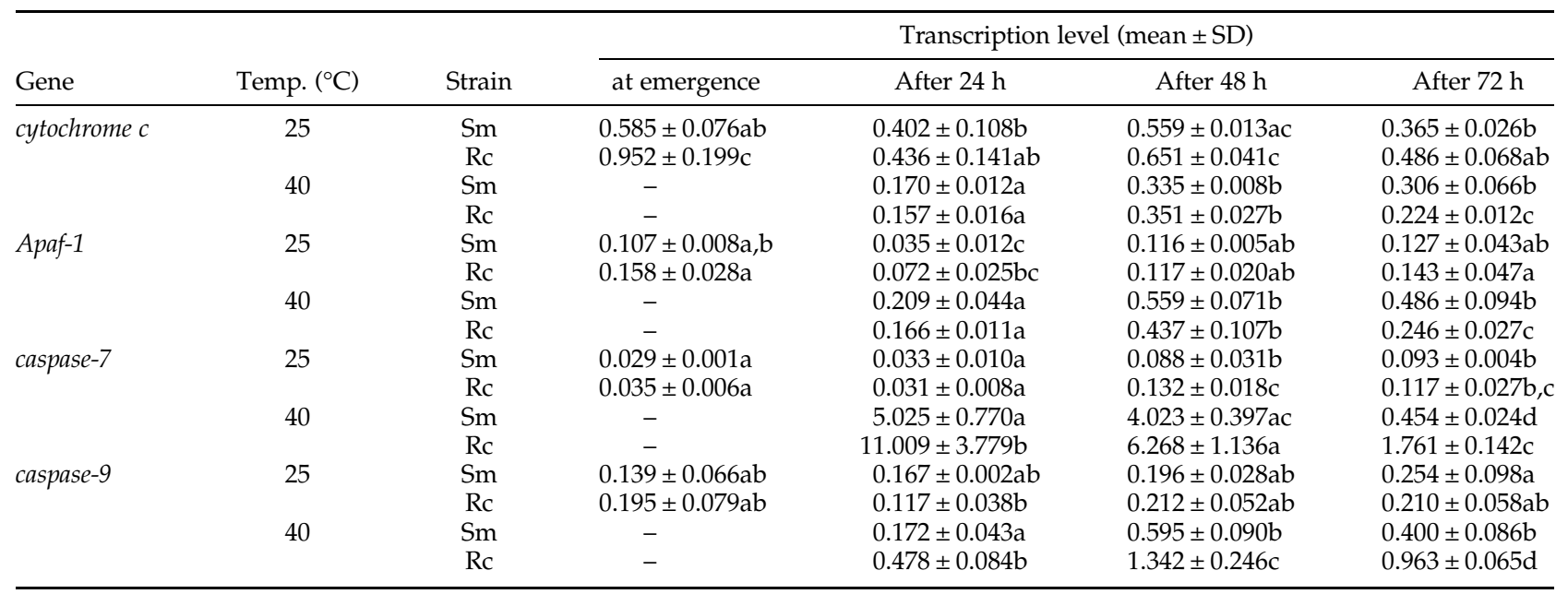

Notes: Temp. corresponds to temperature. For each gene and for each temperature, means followed by different letters are significantly different (Dunn's tests, $P \leq 0.05$ ). 
Lower fitness and physiological impact in a DBM resistant strain

Table 5. Comparative values of several life history traits between the susceptible and resistant DBM strains.

Difference between resistant indiv. compared with susceptible indiv.

\begin{tabular}{|c|c|c|c|}
\hline Life history trait & $\begin{array}{l}\text { at 'normal' temperature } \\
\left(25-30^{\circ} \mathrm{C}\right)\end{array}$ & $\begin{array}{c}\text { at elevated temperature } \\
\left(33.5-40^{\circ} \mathrm{C}\right)\end{array}$ & Reference \\
\hline Neonate number & 0 & 0 & Liu et al. (2008) \\
\hline Survival rate from neonate to 2 nd instar & 0 & 0 & Liu et al. (2008) \\
\hline Pupation rate & 0 & 0 & Liu et al. (2008) \\
\hline Pupa body rate & 0 & 0 & Liu et al. (2008) \\
\hline Copulation rate & 0 & 0 & Liu et al. (2008) \\
\hline Adult longevity & 0 & + & Zhang et al. (2015a) \\
\hline Adult mortality rate & + & + & This study \\
\hline Wing damages & + & + & Zhang et al. (2015b) \\
\hline Female fecundity & + & ++ & Zhang et al. 2015a; Liu et al., 2008 \\
\hline Adult emergence rate & + & ++ & Zhang et al. (2015b) \\
\hline
\end{tabular}

For a given trait, ' 0 ' means that the value of the trait was not statistically different in the two strains and ' + ' $\left({ }^{\prime}++{ }^{\prime}\right)$ means that individuals of the resistant strains had a lower (much lower) value for this trait.

and $40^{\circ} \mathrm{C}$ ), greater damage to ovary and sperm cells was observed in resistant than in susceptible adults. This damage may have a detrimental impact on male and female fertility in individuals of the resistant strain, with possible effects on fecundity, as documented by Liu et al. (2008) and Zhang et al. (2015a).

The greater damage to reproductive cells in resistant than in susceptible individuals may be directly linked to the higher ROS contents in resistant than in susceptible individuals (see below). Indeed, excessively high levels of ROS have been shown to play an important role in the pathogenesis of many reproductive disorders in human (Agarwal et al., 2003). In insects, DeJong et al. (2007) provided strong evidence for a direct impact of cumulative oxidative damage due to ROS on fecundity in the Anopheles gambiae mosquito. Consistent with the known effect of ROS on reproductive cells in insects, the depletion of CAT - a strong antioxidant enzyme that breaks down ROS - has been shown to result in the production of smaller numbers of oocytes by the phlebotomine sand fly Lutzomyia longipalpis after blood feeding (Diaz-Albiter et al., 2011). Similarly, Sim \& Denlinger (2011) found that the inhibition of CAT activity resulted in greater damage to the ovaries of the Culex pipiens mosquito. Consistent with these findings, we found that CAT activity levels were lower in resistant than in susceptible DBM.

\section{Oxidative stress and ROS}

In a previous study (Zhang et al., 2015b), we evaluated the levels of three antioxidant and detoxifying enzymes: GST, P450 and CarE. At $25^{\circ} \mathrm{C}$, resistant $\mathrm{DBM}$ produced larger amounts of GST and P450 and smaller amounts of CarE than susceptible DBM (Table 6). The production of these three enzymes was inhibited at both 36 and $40^{\circ} \mathrm{C}$, for both types of individuals, but this inhibition was significantly stronger in resistant than in susceptible DBM (Table 6). Like CarE, the three additional antioxidant enzymes tested here (CAT, SOD and POD) displayed lower levels of basal expression in resistant individuals (Table 6). However, by contrast to
CarE, GST and P450, the difference in enzymatic activity between resistant and susceptible individuals did not increase further after exposure of the adults to higher temperatures (Table 6). Cells produce antioxidant enzymes in response to the oxidative stress induced by ROS in the mitochondria. As expected, ROS content was therefore higher in resistant than in susceptible individuals, but this difference in content remained roughly constant at all temperatures tested. The production of larger amounts of ROS may decrease the investment in reproduction (see above) or in other functions, such as immunity (thereby increasing the risk of death), and damage may accumulate faster (thereby accelerating the aging process) (Monaghan et al., 2009). The higher level of oxidative stress in resistant than in susceptible individuals may therefore be the key to the difference in fitness between our two strains of the DBM.

\section{Apoptotic genes}

In a previous study (Zhang et al., 2015b), we carried out a comparative analysis of the expression of the four apoptotic genes tested here (cytochrome $c$, Apaf-1, caspases-7 and -9) during the pupal stage in DBM (Table 7). Resistant pupae had a higher basal level of expression and displayed stronger upregulation of three of these genes than susceptible pupae. The exception was the cytochrome $c$ gene, which was more strongly upregulated in resistant pupae, but had similar levels of basal expression in the two types of pupae. In adults, we observed no differences in the basal expression of these four apoptotic genes between resistant and susceptible individuals, with stronger upregulation of the caspases- 7 and -9 genes in resistant adults (Table 7 ). Overall, our results suggest that the resistant strain displays a higher level of apoptosis than the susceptible strain that is further increased by the exposure of the individual, at the pupal or adult stage, to unfavorable temperatures. This higher level of apoptosis may, therefore, together with the higher level of oxidative stress, be another physiological component of the difference of fitness between the two strains. 


\section{L.J. Zhang et al.}

Table 6. Relative activities of several antioxidative and detoxifying enzymes in the adults of the susceptible and resistant strains of the DBM.

\begin{tabular}{|c|c|c|c|}
\hline \multirow[b]{2}{*}{ Enzyme } & \multicolumn{2}{|c|}{$\begin{array}{l}\text { Activity in resistant indiv. } \\
\text { compared with susceptible indiv. }\end{array}$} & \multirow[b]{2}{*}{ Reference } \\
\hline & $\begin{array}{c}\text { Activity at 'normal' } \\
\text { temperature } \\
\left(25 / 30^{\circ} \mathrm{C}\right)\end{array}$ & $\begin{array}{l}\text { Activity at high } \\
\text { temperature } \\
\left(40 / 50^{\circ} \mathrm{C}\right)\end{array}$ & \\
\hline GST & + & - & $\begin{array}{l}\text { Zhang et al } \\
\quad(2015 b)\end{array}$ \\
\hline P450 & + & - & $\begin{array}{l}\text { Zhang et al } \\
\quad(2015 b)\end{array}$ \\
\hline CarE & - & -- & $\begin{array}{l}\text { Zhang et al } \\
\quad(2015 b)\end{array}$ \\
\hline SOD & - & - & This study \\
\hline CAT & - & - & This study \\
\hline POD & - & - & This study \\
\hline
\end{tabular}

For a given enzyme, ' - ', ' $--^{\prime}$ and ' + ' mean that the enzyme displayed a lower, much lower and higher activity in individuals of the resistant strain (compared with those of the susceptible strain), respectively.

\section{Heat-shock proteins}

HSPs play a key role in preventing the cellular damage associated with several stresses (Kregel, 2002; King \& MacRae, 2015) and stress-induced apoptosis (Beere, 2004).

HSC70 does not normally respond to heat stress (Kiang \& Tsokos, 1998). Accordingly, hsc70 mRNA levels were not significantly higher at $40^{\circ} \mathrm{C}$ than at $25^{\circ} \mathrm{C}$ and were similar in susceptible and resistant individuals. Unlike HCS70, HSPs generally rapidly increase in abundance in response to thermal stress (King \& MacRae, 2015). An upregulation of the expressions of $h s p 70$ genes in response to heat stress has thus been documented in many lepidopteran pests (Cydia pomonella (Yin et al., 2006), Chilo suppressalis (Cui et al., 2011), Helicoverpa zea (Zhang \& Denlinger, 2010), Spodoptera exigua (Xu et al., 2011) and Spodoptera litura (Shen et al., 2014)), parasitoid wasps (Macrocentrus cingulum (Xu et al., 2010) and Cotesia vestalis (Shi et al., 2013)) and the fruit fly, Drosophila melanogaster (Udaka et al., 2010). Our results are consistent with this general trend, with larger amounts of hsp70 proteins produced at high temperatures.

Here, we found that two hsp genes ( $h s p 20$ and $h s p 69.2 a$ ) had, like $h s c 70$, higher levels of 'basal' expression in resistant than in susceptible individuals (Table 7). At high temperatures, these two genes and two other $h s p 70$ genes ( $h s p 72.2$ and $h s p 72.3)$ displayed weaker upregulation in resistant than in susceptible individuals (Table 7). These findings are consistent with our previous findings for comparative expression analyses and for the upregulation of $h s p$ genes in these resistant and susceptible DBM strains (Table 7).

\section{Toward an overall explanation of the difference of fitness}

The results of this and our previous studies (Liu et al., 2008; Zhang et al., 2011, 2014, 2015a, b, c) provide a comprehensive explanation of why individuals of our resistant strain had a lower fitness than those of its related susceptible strain. At the temperatures to which the insect is normally exposed (about $25-30^{\circ} \mathrm{C}$ ), the decrease in fitness principally manifests as a lower adult emergence rate, lower levels of adult dispersal (due to damage on the wing structure), lower female fecundity and higher mortality. This impact at temperatures optimal for DBM development and survival can be accounted for by: (1) a higher ROS content, possibly due to lower levels of activity for many antioxidant enzymes (e.g. CAT, SOD, CarE, POD) and (2) the overexpression of several genes (such as hsp20 and hsp69.2a). This greater investment in protein synthesis decreases the amount of resources available for other critical functions, accounting, together with the higher ROS content, for the lower longevity of individuals of the resistant strain.

At temperatures above $33.5^{\circ} \mathrm{C}$, the difference of fitness between the two strains increased. All four life history traits affected at favorable temperatures continued to be affected, but the impact on two of these traits (female fecundity (Liu et al., 2008; Zhang et al., 2015a) and adult emergence rate (Zhang et al., 2015b)) increased. In addition, rising temperatures had a deleterious effect on three additional life history traits not affected at favorable temperatures: hatchability, pupal survival rate and adult longevity. This thermosensitivity may be due to both: (1) weaker upregulation of $h s p$ gene expression, although we must keep in mind that a weaker upregulation of a gene does not necessarily mean that its mRNA titer is lower and (2) stronger upregulation of the expression of caspases-7 and -9. Lower HSP levels are associated with lower levels of thermotolerance and protection against a number of stresses other than heat, including ROS injury (Kalmar \& Greensmith, 2009). HSPs also exert anti-apoptotic effects (Garrido et al., 2001; Ravagnan et al., 2001). The weaker upregulation of the genes encoding these proteins, together with the stronger upregulation of apoptotic genes, could, therefore, greatly increase apoptosis levels at high temperatures.

\section{Fitness cost associated with the ace1R allele in Chinese DBM populations}

The difference in fitness between the susceptible and resistant strains studied here and in our previous studies (Liu et al., 2008; Zhang et al., 2015a, b) might have several non-exclusive origins. Part of this cost is directly linked to the ace $1 R$ - the allele conferring the resistance to several to several OP insecticides - or to other alleles of genes linked to ace1. Indeed, in a previous experiment and using the same strains, we monitored the frequency of $a c e 1 R$ (by genotyping more than 20,000 adults) and the level of resistance (through bioassays on more than 50,000 individuals) over several generations (Zhang et al., 2015a). For all strains, replicates and experimental conditions, we observed a decrease in the level of resistance to chlorpyrifos (an OP) over time, in the generations reared in the absence of chlorpyrifos. This decrease in resistance was associated with a decrease in the frequency of the ace $1 R$ allele over generations. This clearly indicated that $a c e 1 R$ - or closely linked alleles - is costly in the absence of insecticide. This cost is a general tendency (Kliot \& Ghanim, 2012). Indeed, considerable disadvantages in terms of life history traits and physiological processes have been found to be associated with insecticide resistance due to mutations and/or the overexpression of resistance alleles in many insect species: $P$. xylostella (the DBM) (Liu et al., 2008), Leptinotarsa decemlineata (Zhu et al., 1996), Culex quinquefasciatus (Berticat et al., 2008), Culex pipiens (Bourguet et al., 2004), A. gambiae (Djogbénou et al., 2010), Aedes aegypti (Martins et al., 2012), Myzus persicae (Castañeda et al., 2011), and several species of Drosophila (Shi et al., 2004). 
Table 7. Relative gene expression of several hsps genes and apoptotic genes in the susceptible and resistant DBM strains.

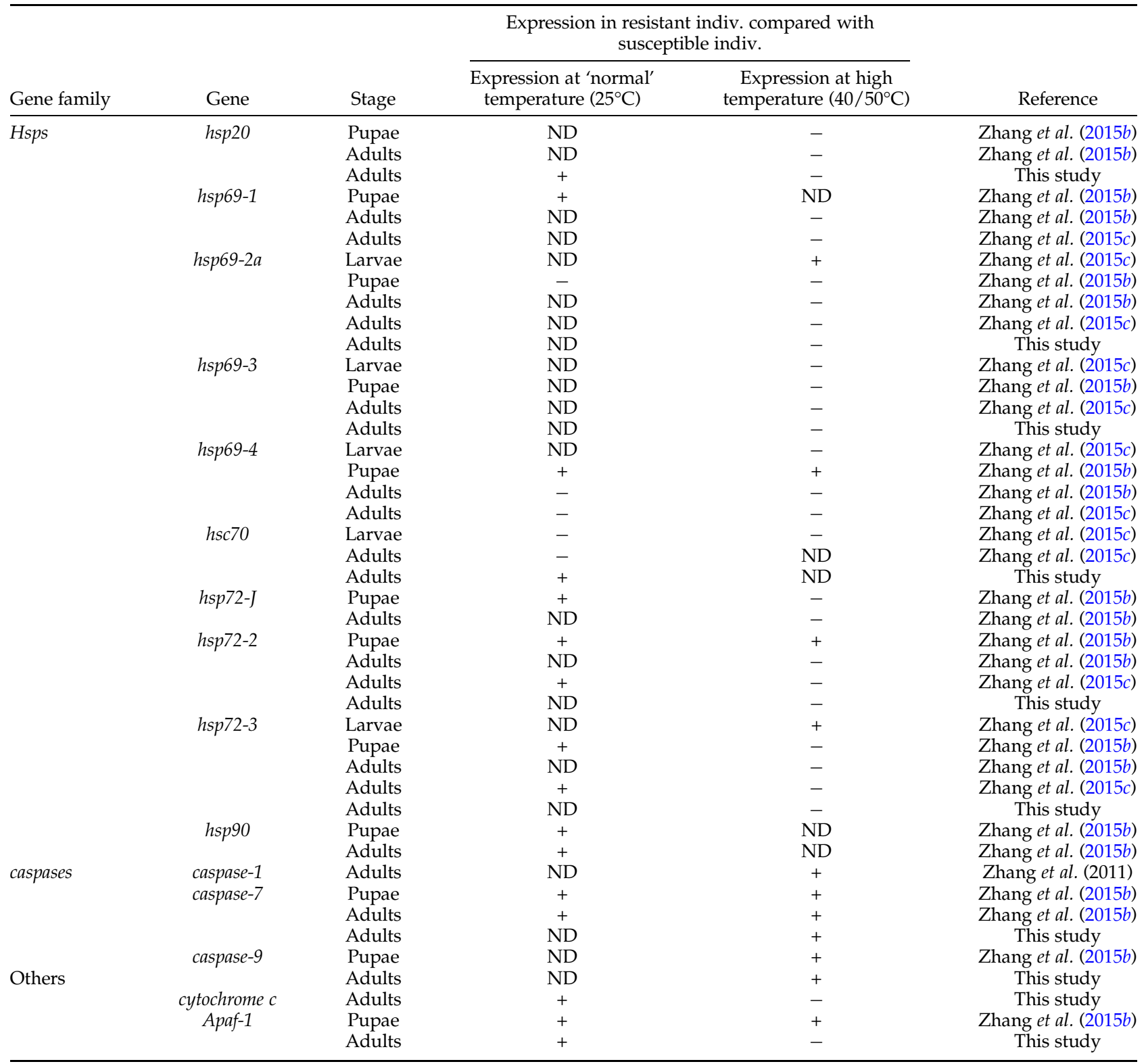

For a given gene, ' - ' and ' + ' mean that the enzyme displayed a lower and higher expression in individuals of the resistant strain (compared with those of the susceptible strain), respectively. ND means not determined.

In our previous experiment, we also showed that the frequency of $a c e 1 R$ resistance allele decreased faster at high temperature than at optimal temperature. In other words, the fitness cost associated with ace $1 R$ is temperature sensitive (Zhang et al., 2015a), a feature reported for resistances to other insecticides in the DBM (Li et al., 2007).

The decrease in fitness in the resistant strain might correspond to a fitness cost associated with $a c e 1 R$ also partly be due to genetic divergence at loci unlinked to ace1. The susceptible and resistant strains originated from the same 2005 collection and may have a rather similar genetic background; however, they have undergone different selective pressures in the laboratory and have probably undergone bottlenecks during that time. Ten years of laboratory culturing is likely to have had a major impact on the genome. In addition, it is hard to believe that all of the phenotypic and expression differences reported here and in our previous studies (Liu et al., 2008; Zhang et al., 2015a, b) are simply due to two amino acid substitutions in ace1. Indeed, the $a c e 1 R$ resistance allele differed from susceptible alleles by two tightly linked mutations A201S and G227A - affecting the amino acid sequence of the acetylcholinesterase enzyme (Zhang et al., 2015a). This change in two amino acids probably modifies the substrate specificity of the active site of this enzyme (i.e. it certainly reduced the affinity between OP insecticides and the acetylcholinesterase). To our knowledge, there is no direct interaction between 


\section{L.J. Zhang et al.}

acetylcholinesterase and either the oxidative stress or the physiological cascade leading to apoptosis. The factors governing the differential expression or regulation of $h s p$ genes and apoptotic genes therefore remain to be identified.

\section{Supplementary material}

The supplementary material for this article can be found at https://doi.org/10.1017/S0007485317000049.

\section{Acknowledgments}

This study received financial support from the National Natural Science Foundation of China (NNSFC) (grant no. 31272049) and the Key Foundation of Technology project of Fujian Province (grant no. 2014N0003).

\section{Conflict of interest}

None.

\section{Author contributions}

DB and GW conceived the experiments, analyzed the data, generated the tables, produced the figures and wrote the manuscript. LJZ, GW, JLC, BLY and XGK performed the experiments.

\section{References}

Abrashev, R.I., Pashova, S.B., Stefanova, L.N., Vassilev, S.V., Dolashka-Angelova, P.A. \& Angelova, M.B. (2008) Heat-shock-induced oxidative stress and antioxidant response in Aspergillus niger. Canadian Journal of Microbiology 54, 783-799.

Agarwal, A., Saleh, R.A. \& Bedaiwy, M.A. (2003) Role of reactive oxygen species in the pathophysiology of human reproduction. Fertility and Sterility 79, 829-843.

An, M.I. \& Choi, C.Y. (2010) Activity of antioxidant enzymes and physiological responses in ark shell, Scapharca broughtonii, exposed to thermal and osmotic stress: effects on hemolymph and biochemical parameters. Comparative Biochemistry and Physiology - Part B 155, 34-42.

Atwal, A.S. (1955) Influence of temperature, photoperiod, and food on the speed of development, longevity, fecundity, and other qualities of the Diamond-Back moth Plutella maculipennis (Curtis) (Lepidoptera: Tineidae). Australian Journal of Zoology 3, 185-221.

Bahrndorff, S., Mariën, J., Loeschcke, V. \& Ellers, J. (2009) Dynamics of heat-induced thermal stress resistance and Hsp70 expression in the springtail, Orchesella cincta. Functional Ecology 23, 233-239.

Barbehenn, R.V. (2002) Gut-based antioxidant enzymes in a polyphagous and a graminivorous grasshopper. Journal of Chemical Ecology 28, 1329-1347.

Beere, H.M. (2004) "The stress of dying": the role of heat shock proteins in the regulation of apoptosis. Journal of Cell Science 117, 2641-2651.

Berticat, C., Bonnet, J., Duchon, S., Agnew, P., Weill, M. \& Corbel, V. (2008) Costs and benefits of multiple resistance to insecticides for Culex quinquefasciatus mosquitoes. BMC Evolutionary Biology 8, 104.

Bourguet, D., Guillemaud, T., Chevillon, C. \& Raymond, M. (2004) Fitness cost of insecticide resistance in natural breeding sites of the mosquito Culex pipiens. Evolution 58, 128-135.

Bradford, M.M. (1976) A rapid and sensitive method for the quantitation of microgram quantities of protein unitizing the principle of protein dye binding. Annals of Biochemistry 72, 248-254.

Calabria, G., Dolgova, O., Rego, C., Castañeda, L.E., Rezende, E. L., Balanyà, J., Pascual, M., Sørensen, J.G., Loeschcke, V. \& Santos, M. (2012) Hsp70 protein levels and thermotolerance in Drosophila subobscura: a reassessment of the thermal co-adaptation hypothesis. Journal of Evolutionary Biology 25, 691-700.

Castañeda, L., Baeeientos, K., Cortes, P.A., Figueroa, C., Fuentescontreras, E., Luna-Rudloff, M., Silva, A.X. \& Bacigalupe, L. D. (2011) Evaluating reproductive fitness and metabolic costs for insecticide resistance in Myzus persicae from Chile. Physiological Entomology 36, 253-260.

Chang, H.Y. \& Yang, X. (2000) Proteases for cell suicide: functions and regulation of caspases. Microbiology and Molecular Biology Reviews 64, 821-846.

Chowdhury, I., Tharakan, B. \& Bhat, G.K. (2006) Current concepts in apoptosis: the physiological suicide program revisited. Cellular and Molecular Biology Letters 11, 506-525.

Circu, M.L. \& Aw, T.Y. (2010) Reactive oxygen species, cellular redox systems, and apoptosis. Free Radical Biology and Medicine 48, 749-762.

Colinet, H., Sinclair, B.J., Vernon, P. \& Renault, D. (2015) Insects in fluctuating thermal environments. Annual Review of Entomology 60, 123-140.

Cui, Y., Du, Y., Lu, M. \& Qiang, C. (2011) Antioxidant responses of Chilo suppressalis (Lepidoptera: Pyralidae) larvae exposed to thermal stress. Journal of Thermal Biology 36, 292-297.

Cullen, S.P. \& Martin, S.J. (2009) Caspase activation pathways: some recent progress. Cell Death and Differentiation 16, 935-938.

Daugaard, M., Rohde, M. \& Jäättelä, M. (2007) The heat shock protein 70 family: highly homologous proteins with overlapping and distinct functions. FEBS Letter 581, 3702-3710.

DeJong, R.J., Miller, L.M., Molina-Cruz, A., Gupta, L., Kumar, S. \& Barillas-Mury, C. (2007) Reactive oxygen species detoxification by catalase is a major determinant of fecundity in the mosquito Anopheles gambiae. Proceedings of the National Academy of Sciences of the United States of America 104, 2121-2126.

Djogbénou, L., Noel, V. \& Agnew, P. (2010) Costs of insensitive acetylcholinesterase insecticide resistance for the malaria vector. Anopheles gambiae homozygous for the G119S mutation. Malaria Journal 19, 12.

Diaz-Albiter, H., Mitford, R., Genta, F., Mauricio, R.V., Anna, S., Rod, J. \& Dillon, R.J. (2011) Reactive oxygen species scavenging by catalase is important for female Lutzomyia longipalpis fecundity and mortality. PLoS ONE 6, e17486.

Fahmy, N.M. (2012) Impact of two insect growth regulators on the enhancement of oxidative stress and antioxidant efficiency of the cotton leaf worm, Spodoptera littoralis (Biosd.). Egyptian Academic Journal of Biological Science 5, 137-149.

Furlong, M.J., Wright, D.J. \& Dosdall, L.M. (2013) Diamondback moth ecology and managements: problems, progress, and prospects. Annual Review of Entomology 58, 517-541.

Garrido, C., Gurbuxani, S., Ravagnan, L. \& Kroemer, G. (2001) Heat shock proteins: endogenous modulators of apoptotic cell death. Biochemical and Biophysical Research Communications 286, 433-442.

Jia, F.X., Dou, W., Hu, F. \& Wang, J.J. (2011) Effects of thermal stress on lipid peroxidation and antioxidant enzyme activity 
of oriental fruit fly, Bactrocera dorsalis (Diptera: Tephritidae). Florida Entomologist 94, 956-963.

Kalmar, B. \& Greensmith, L. (2009) Induction of heat shock proteins for protection against oxidative stress. Advanced Drug Delivery Reviews 61, 310-318.

Karlin, S. \& Brocchieri, L. (1998) Heat shock protein family: multiple sequence comparisons, function and evolution. Journal of Molecular Evolution 47, 565-577.

Kiang, J.G. \& Tsokos, G.C. (1998) Heat shock protein 70 kDa: molecular biology, biochemistry, and physiology. Pharmacology \& Therapeutics 80, 183-201.

King, A.M. \& Macrae, T.H. (2015) Insect heat shock proteins during stress and diapause. Annual Review of Entomology 60, 59-75.

Kliot, A. \& Ghanim, M. (2012) Fitness costs associated with insecticide resistance. Pest Management Science 68, 14311437.

Konca, K., Lankoff, A., Banasik, A., Lisowska, H., Kuszewski, T., Gozdz, S., Kaza, Z. \& Wojcik, A. (2003) A cross-platform public domain PC image-analysis program for the comet assay. Mutation Research 534, 15-20.

Krebs, R.A. \& Feder, M.E. (1997) Tissue special variation in Hsp70 expression and thermal damage in Drosophila melanogaster larvae. Journal of Experimental Biology 200, 2007-2015.

Kregel, K.C. (2002) Heat shock proteins: modifying factors in physiological stress responses and acquired thermotolerance. Journal of Applied Physiology 92, 2177-2186.

Larionov, A., Krause, A. \& Miller, W. (2005) A standard curve based method for relative real time PCR data processing. BMC Bioinformatics 6, 62 .

Li, Z.M., Liu, S.S., Liu, Y.Q. \& Ye, G.Y. (2007) Temperaturerelated fitness costs of resistance to spinosad in the diamondback moth, Plutella xylostella (Lepidoptera: Plutelidae). Bulletin of Entomological Research 97, 627-635.

Liu, Y.S. \& Wu, J.Y. (2006) Hydrogen peroxide-induced astaxanthin biosynthesis and catalase activity in Xanthophyllomyces dendrorhous. Applied Microbiology and Biotechnology 73, 663-668.

Liu, X.L., Zhang, S.Z., Shan, X.Q., et al. (2007) Combined toxicity of cadmium and arsenate to wheat seedings and plant uptake and antioxidative enzyme responses to cadmium and arsenate contamination. Ecotoxicology and Environmental Safe 68, 305-313.

Liu, F., Miyata, T., Wu, Z.J., Li, C.W., Wu, G., Zhao, S.X. \& Xie, L. H. (2008) Effects of temperature on fitness costs, insecticide susceptibility and heat shock protein 70 in insecticideresistant and susceptible Plutella xylostella. Pesticide Biochemistry and Physiology 91, 45-52.

Mahroof, R., Zhu, K.Y., Neven, L., Sunramanyam, B. \& Bai, J. (2005) Expression patterns of three heat shock protein 70 genes among developmental stages of the red flour beetle, Tribolium castaneum (Coleoptera: Tenebrionidae). Comparative Biochemistry and Physiology 141, 247-256.

Marklund, D. \& Marklund, G. (1974) Involvement of superoxide anion radical in auto-oxidation of pyrogallol. A convenient assay for superoxide dismutase. European Journal of Biochemistry 47, 469-474.

Marsh, H.O. (1917) Life history of Plutella maculipennis, the diamondback moth. Journal of Agricultural Research 10, 1-10.

Martins, A.J., Ribeiro, C., Bellinato, D.F., Peixoto, A.A., Valle, D. \& Lima, J.B.P. (2012) Effect of insecticide resistance on development, longevity and reproduction of field or laboratory selected Aedes aegypti populations. PLoS ONE 7, e31889.
Monaghan, P., Metcalfe, N.B. \& Torres, R. (2009) Oxidative stress as a mediator of life history trade-offs: mechanisms, measurements and interpretation. Ecology Letters 12, 75-92.

Nover, L. \& Scharf, K.D. (1997) Heat stress proteins and transcription factors. Cellular and Molecular Life Sciences 53, 80-103.

Parsell, D.A. \& Lindquist, S. (1993) The function of heat-shock proteins in stress tolerance: degradation and reactivation of damaged proteins. Annual Review of Genetics 27, 437-456.

Ravagnan, L., Gurbuxani, S., Susin, S.A., Maisse, C., Daugas, E., Zamzami, N., Mak, T., Jäättelä, M., Penninger, J.M., Garrido, C. \& Kroemer, G. (2001) Heat-shock protein 70 antagonizes apoptosis-inducing factor. Nature Cell Biology 3, 839-843.

Rinehart, J.P., Yocum, G.D. \& Denlinger, D.L. (2000) Developmental upregulation of inducible hsp70 transcripts, but not the cognate form, during pupal diapause in the flesh fly, Sarcophaga crassipalpis. Insect Biochemistry and Molecular Biology 30, 515-521.

R Development Core Team. (2015) R: A language and environment for statistical computing (Version 3.2.2) [Computer software]. Available online at https://www.r-project.org/ index .html

Schneider, K. \& Schlegel, H.G. (1981) Production of superoxide radicals by soluble hydrogenase from Akcaligeneseutro phus H16. Biochemical Journal 193, 99-107.

Shen, Y., Gong, Y.J., Gu, J., Huang, L.H. \& Feng, Q.L. (2014) Physiological effect of mild thermal stress and its induction of gene expression in the common cutworm, Spodoptera litura. Journal of Insect Physiology 61, 34-41.

Shi, M.A., Lougarre, A., Alies, C., Fremaux, I., Tang, Z.H. \& Fournier, D. (2004) Acetylcholinesterase alterations reveal the fitness cost of mutations conferring insecticide resistance. BMC Evolutionary Biology 4, 5.

Shi, M., Wang, Y.N., Zhu, N. \& Chen, X.X. (2013) Four heat shock protein genes of the endoparasitoid wasp, Cotesia vestalis, and their transcriptional profiles in relation to developmental stages and temperature. PLOS ONE 8, e59721.

Sim, C. \& Denlinger, D.L. (2011) Catalase and superoxide dismutase-2 enhance survival and protect ovaries during overwintering diapause in the mosquito Culex pipiens. Journal of Insect Physiology 57, 628-634.

Singh, N.P., McCoy, M.T., Tice, R.R. \& Schneider, E.L. (1988) A simple technique for quantification of low levels of DNA damage in individual cells. Experimental Cell Research 17, 184-191.

Udaka, H., Ueda, C. \& Goto, S.G. (2010) Survival rate and expression of Heat-shock protein 70 and Frost genes after temperature stress in Drosophila melanogaster lines that are selected for recovery time from temperature coma. Journal of Insect Physiology 56, 1889-1894.

Xu, P., Xiao, J., Liu, L., Li, T. \& Huang, D. (2010) Molecular cloning and characterization of four heat shock protein genes from Macrocentrus cingulum (Hymenoptera: Braconidae). Molecular Biology Reports 37, 2265-2272.

Xu, Q., Zou, Q., Zheng, H., Zhang, F., Tang, B. \& Wang, S. (2011) Three heat shock proteins from Spodoptera exigua: gene cloning, characterization and comparative stress response during heat and cold shocks. Comparative Biochemistry and Physiology - Part B 159, 92-102.

Yang, L.H., Huang, H. \& Wang, J.J. (2010) Antioxidant responses of citrus red mite, Panonychus citri (McGregor) (Acari: Tetranychidae), exposed to thermal stress. Journal of Insect Physiology 56, 1871-1876. 


\section{L.J. Zhang et al.}

Yin, X., Wang, S., Tang, J., Hansen, D. \& Lurie, S. (2006) Thermal conditioning of fifth-instar Cydia pomonella (Lepidoptera: Tortricidae) affects HSP70 accumulation and insect mortality. Physiological Entomology 31, 241-247.

Yun, L., Chuanqing, R., Bo, L. \& Yujing, Z. (2013) Effects of temperature on oviposition and longevity of adult diamondback moth (Plutella xylostella L.). Chinese Agricultural Science Bulletin 12, 035.

Zhang, Q. \& Denlinger, D.L. (2010) Molecular characterization of heat shock protein 90, 70 and 70 cognate cDNAs and their expression patterns during thermal stress and pupal diapause in the corn earworm. Journal of Insect Physiology 56, 138-150.

Zhang, L.J., Wang, K.F., Zhuang, H.M. \& Wu, G. (2014) Identifications of cytochrome $c$ and Apaf-1 and their mRNA expressions under heat stress in insecticide-susceptible and -resistant Plutella xylostella (Lepidoptera: Plutellidae). European Journal of Entomology 111, 457-468.

Zhang, L.J., Jing, Y.P., Li, X.H., Li, C.W., Bourguet, D. \& Wu, G. (2015a) Temperature-sensitive fitness cost of insecticide resistance in Chinese populations of the diamondback moth Plutella xylostella. Molecular Ecology 24, 1611-1627.

Zhang, L.J., Wu, Z.L., Wang, K.F., Liu, Q., Zhuang, H.M. \& Wu, G. (2015b) Trade-off between thermal tolerance and insecticide resistance in Plutella xylostella. Ecology $\mathcal{E}$ Evolution $5,515-530$.

Zhang, L.J., Wang, K.F., Zhuang, H.M., Jing, Y.P. \& Wu, G. (2015c) Identifications of $h s p 70$ sand $h s c 70$ and mRNA expressions under heat stress in insecticide-resistant and -susceptible Plutella xylostella (Lepidoptera: Plutellidae). European Journal of Entomology 112, 215-226.

Zhu, K.Y., Lee, S.H. \& Clark, M. (1996) A point mutation of acetylcholinesterase associated with azinphosmethyl resistance and reduced fitness in Colorado potato beetle. Pesticide Biochemistry and Physiology 55, 100-108.

Zhuang, H.M., Wuang, K.F., Miyata, T., Wu, Z.J., Wu, G. \& Xie, L.H. (2011) Identification and expression of caspase-1 gene under heat stress in insecticide-susceptible and -resistant Plutella xylostella (Lepidoptera: Plutellidae). Molecular Biology Reports 38, 2529-2539. 